\title{
Workforce modernisation in the police service
}

\author{
Barry Loveday \\ Institute of Criminal Justice Studies, University of Portsmouth, Ravelin House, Museum \\ Road, Portsmouth, PO1 2QQ. Email: Barry.loveday@port.ac.uk \\ Received 6 September 2006; revised and accepted 23 October 2007 \\ Keywords: workforce modernisation, police hierarchies, piloting \\ modernisation, Investigative Support Officers
}

Barry Loveday is Reader in Criminal Justice at the University of Portsmouth. He has published extensively in the field of police management, accountability and police supervision.

\begin{abstract}
This article considers the application and potential impact of workforce modernisation in England and Wales. It highlights some problems surrounding current police hierarchies and specialisation particularly in relation to the decline in visible policing. It suggests that bureaucratic growth within police forces can be matched to a decline in effective command and control of police services. Lengthened chains of command and narrower spans of control have, within larger police forces, diluted the supervisory capacity and effectiveness of police managers. It is argued that this feature reinforces the need for smaller, more manageable units of policing. The article thereafter highlights a central theme identified within HMIC's 2004 Thematic Report on Modernising the Police Service. This is the creation of a career pathway for all police personnel and, long term, the ability to move between warranted and nonwarranted police posts. It recognises the positive position taken by ACPO in relation to modernisation. It also draws on data collected from one workforce modernisation pilot site, Bexley Operational Command Unit (OCU), particularly in relation to the successful use of police staff 'Investigative Support Officers' in processing
\end{abstract}

low-level cases. Evidence from the Bexley site indicates that workforce modernisation strategy provides the opportunity to improve both overall police effectiveness and the relationship between police and community.

\section{INTRODUCTION}

Following the decision on the part of the Home Secretary not to go forward with the amalgamation of police forces in mid 2006, the new Minister for Policing Security and Community Safety was to circulate a letter to all police chiefs and police authority chairs outlining plans for ongoing police reform and enhancement of protective services (Home Office, 2006). Within this continuing reform programme the Minister was to highlight the need to reinforce reform in relation to workforce development and modernisation 'so that policing has the right people with the right training and skills in the right places' (Home Office, 2006, p. 1).

\section{WORKFORCE MODERNISATION}

Workforce modernisation within the police service materially reflects the commitment of New Labour to modernise all public services to improve their efficiency and overall capability. The commitment to reform within the police service has been 
most recently highlighted both by the 2004 HMIC 'Thematic Report on Modernising the Police Service' and latterly by the piloting in four police force areas of new 'mixed economy' police teams. The mixed economy teams consist of one police constable exercising a managerial role over five to seven police staff who have taken on either public reassurance policing duties or those of criminal investigation. Early reports from the sites indicate that the mixed economy team approach is proving to be highly successful and could be the prelude to significant developments in police service delivery which, if fully implemented, could fundamentally alter the policing landscape in England and Wales (Loveday, 2006a).

The nature and extent of reform now being contemplated reflects the fact that, as currently configured, police establishment within the 43 forces may not provide value for money and often offers little in the way of remedy for local communities experiencing anti-social behaviour which continues to dominate the agenda in both urban and rural areas. This has proved to be most evident in the difficulty which police services continue to experience in delivering 'visible policing' within local communities and the concurrent problem of fear of crime which currently remains the highest recorded in Europe.

A number of factors both internal and external to the police may provide some explanation for this. As currently established the rank hierarchy and career structure of the police service may militate against the better provision of the basic patrol 'visible uniformed policing' within the community. However, external factors can also be identified. These would include both ever increasing public demand for more policing and linked with and arising from recent legislation the bureaucratic requirements placed on the police service, particularly those relating to the arrest of and charging of suspects at the police station.
It is nevertheless difficult to explain the current crisis in the delivery of basic police services as a consequence of external circumstances. Many internal factors also impede the delivery of police services. These would include the police hierarchy and career progression at one level and the lack of effective management at local level. It would also include current use (or misuse) of police staff within many police forces.

\section{A REDUNDANT POLICE HIERARCHY}

As currently constituted the police service is characterised by an extravagant hierarchical structure that, in its inception, replicated an army rank system established in the nineteenth century. Every rank was to be closely supervised by a higher rank with a numerical component which dictated the number of senior officers made immediately responsible for their duties. A defined number of constables would be made the immediate responsibility of sergeants who in turn were responsible to inspectors and so on up the police hierarchy. Within any force there will be at least five supervisory ranks above that of the constable. If all ranks were to be identified including that extending to Chief Officer rank, then the number of supervisory ranks rises to no fewer than eight more senior ranks above that of constable.

Career progression for all officers is through the ranks by way of promotion usually following paper-based examinations. Pay rewards are linked to rank rather than responsibility and it is for this reason that the patrol function (visible policing) has never proved to be a way to achieving professional career success (Loveday, 1998). This perception has been encouraged where police forces have traditionally placed greater emphasis on specialised functions and services and this was to be best reflected in the rise of the Criminal Investigation 
Department (CID) where the number of senior posts available was always greater than within the uniformed service.

The over-extended police hierarchy has been the source of bureaucratic growth over time. It has also, when aligned with police force amalgamation and specialisation, generated major management problems in relation to the effective command and control of police services. Over a number of decades (but particularly the 1970s) police forces were to extend their professional hierarchies (Young, 1991). With this went the growth of specialised units which also were to serve to narrow spans of management control significantly. This situation was to be encouraged by police managers, particularly in America where the police professional model of clear functional specialisation was to be exemplified in the big city police departments (Wilson, 1950).

Yet as spans of control narrowed and chains of command lengthened, immediate supervision of operational officers effectively ceased. Just how big a problem this could create was to be made manifest in the activities of the West Midlands Serious Crime Squad and was to provide a useful guide to the consequences of extended hierarchies and narrow spans of control. It created a lax and largely unmanageable police structure where operational and management control could be exercised not by senior or even ACPO-ranked officers but by the lowest supervisory rank, that of sergeant. In the West Midlands it was these officers who effectively ran the Serious Crime Squad and were ultimately to bring the squad into total disrepute (Kaye, 1991).

A solution to the inherent dangers of extended chains of command and specialisation was to be temporarily provided by the arrival in the 1990s of the Basic Command Unit. This unit of policing was planned to consist of no more than 250 police officers, a number that could be effectively managed by one superintendent (O'Byrne, 2001). Identified as the building blocks of the police service, the BCU significantly expanded spans of control, whilst also significantly reducing chains of command. Within the BCU one senior officer exercised oversight over the whole range of police functions. Yet despite the benefits arising from the $\mathrm{BCU}$, the recent history of these units has been one of steady expansion in establishment to a point where the average size of the $\mathrm{BCU}$ has risen to at least 450 officers and where some BCUs have establishments of over 1,000 officers (O’Byrne).

Currently the predisposition to increase the size of the BCU like that of police forces appears to be based very largely on professional judgment rather than any independent analysis (O'Byrne, 2001). There has been little or no attempt by professional associations to identify what constitutes in police establishment terms a viable BCU. The absence of independent evaluation has been most recently subject to critical comment by the Police Superintendents Association whose members are most immediately, as BCU commanders, confronted with the consequences of this important managerial failure (Police Superintendents Association, 2004).

\section{SPECIALISATION AND THE DECLINE OF VISIBLE POLICING}

One further problem confronting all police services has been the growth of specialisation within policing. Specialisation has been for many years a central feature of police services (Martin \& Wilson, 1969). However, over recent decades the rise of specialist units has limited significantly the ability of police forces to deliver effective visible policing. This may in part have been a reflection of the pressures from the centre, particularly those emanating from Her Majesty's Inspectorate of Constabulary 
(HMIC), which has required all forces, whatever their size, to demonstrate a degree of omni-competence in specialised services which have been subsequently subject to close monitoring by HMIC through successive annual efficiency reports.

Providing sufficient manpower to support ever-increasing specialisation was, however, usually to be sustained at the expense of visible policing and patrol strength. This problem was to be identified and explored in some detail over 20 years ago by senior police managers who questioned the need for such specialisation within all police forces (Jones, 1980). Yet the problem of police officer 'abstraction', where uniform strength is reallocated to support specialised functions, continues to be a critical problem within the current police system. This in fact has been noted very recently by a police officer (wishing to remain anonymous) who has argued that:

As a community beat officer a lot of my time is now taken up supporting understrength shifts rather than performing my core tasks. I managed to check our shift rotas back to 1999 and in that period the number of frontline officers in my sub-division has dropped by around 30 per cent to 40 per cent, although various other department strengths have increased significantly (Police Review, 2006, p. 17).

Professional demands and the identification of new threats can also impact on the availability of visible policing presence on the streets. This has been demonstrated most recently by the professional assessment made within HMIC that the inadequacy of 'protective services' within the police service meant that police forces, as currently constituted, were not 'fit for purpose'. In its 2005 Report, 'Closing the Gap', HMIC was to argue for a reconfiguration of policing around a merger plan to create vast regional forces with the capacity to provide and support 'protective services' now deemed a central requirement to contemporary policing (HMIC, 2005).

As with BCUs and so too with police forces, the professional solution to new challenges always appeared to be based on ever larger units of policing. Little evidence of any assessment of costs/benefit analysis of such organisational change appeared to have been undertaken (Loveday, 2006b). Statistical evidence presented in support of mergers by HMIC was to be undermined by independent analysis of the data (Loveday, 2006b). It was to confirm the lack of methodological rigour that has on occasion characterised reports presented by HMIC and that also appeared to be reflected in its 2005 Report, 'Closing the Gap' (O'Byrne, 2001).

Yet ironically HMIC had within the Thematic Report of 2004 already identified what could prove, if implemented, to be one of the most cost-effective ways of improving police efficiency and effectiveness. The 'Report on Modernising the Police Service' (HMIC, 2004) was to set out a future strategy of reform that sought for the first time to professionalise the police service while also making much more effective use of all of those employed within it.

\section{HMIC THEMATIC REPORT ON MODERNISING THE POLICE SERVICE}

At the time of its publication, HMIC's Thematic Report (HMIC, 2004) received very little publicity. This did less than justice to the nature of reform of the police service proposed within it. It challenged decades of police resistance to change by recommending the end of a single entry point into the police service and its replacement by multiple entry points and the creation of common conditions of service for all police staff. It also recommended the introduction 
of standard pension rights and alongside this a system of professional registration and development programmes for all employees. This would be matched by a clear career pathway for all staff and the opportunity for these to move between 'warranted and nonwarranted police posts'. If these proposals are implemented they represent the biggest leap made by police forces towards modernisation since their inception in the early nineteenth century.

Among a range of reforms, perhaps the most significant would be a formalisation and extension of the use of police powers to many more members of the "extended police family'. This would include roads policing, patrol, escort, detention and investigation and response duties that currently fall to police officers alone. In line with this the government has initiated within recent and planned legislation the use of police staff to run custody suits and to enable Police Community Support Officers (PCSOs) to exercise limited police powers, operationally, in the exercise of their duties. The expansion of support staff responsibilities has in part reflected the interesting responses received by HMIC from police forces concerning their greater use in the delivery of police services. Of the 41 police forces questioned nearly 66 per cent said that in future police staff could be used to carry out stop-and-search functions; a third stated that staff could be used to make arrests. A majority of forces (60 per cent) also said that police staff could carry out covert policing duties (Herbert \& Gower, 2004).

\section{RESPONSE OF THE POLICE FEDERATION}

The recommendations of HMIC were to be met perhaps not surprisingly with deep suspicion by the Police Federation, towards the attitude and views of which, it is fair to say, the main political parties continue to exhibit what appears to be a permanent apprehension. Indeed, an early draft of the HMIC Thematic Report was to be leaked to the press to coincide with the Federation's 2004, Bournemouth Annual Conference, presumably to ensure that, in this arena at least, the Thematic Report would benefit from the full glare of publicity that its contents were deemed to warrant (Herbert \& Gower, 2004). Yet despite Police Federation opposition, the interesting feature of the modernisation programme is the fragmented nature of the response to it among other police associations. This presents a remarkable contrast to the united response to the Sheehy and Posen Reviews of the 1990s. Sheehy sought to introduce a system of universal contracts and performance pay to all police officers, while the Posen review planned to remove many service functions (and funding) from the police service altogether. Unlike these earlier inquiries and reviews there is now no unified opposition to this reform among police associations. Indeed, both ACPO and more significantly the Police Superintendents Association have welcomed many of HMIC's recommendations.

\section{POSITIVE RESPONSE TO POLICE MODERNISATION BY ACPO}

Evidence of the degree to which ACPO has risen to the challenge presented by the Thematic Report was to be highlighted within a draft report entitled 'ACPO's vision for workforce modernisation' released in early 2006. Condemning the existing workforce model as obsolete and characterised by inefficiency and restrictive practices, the draft report embraces modernisation of working practices and favours the introduction of mixed teams for the delivery of a range of police services. Mixed teams led by a police constable will consist very largely of police support staff, each of whom can be expected to exercise police 
powers in relation to a specific function such as investigation or neighbourhood policing. It is argued that an optimal mix of police support officers and constables could, when linked to ending outdated work practices and employment conditions, substantially increase police output.

The outdated practices alluded to within ACPO's draft report are also likely to extend to both police pay negotiating arrangements and the current police discipline system. Interestingly both of these are now also subject to fundamental review. It is perhaps for this reason that the Police Federation has recently launched a national campaign driven from the regions against the modernisation programme. The Federation has described the ACPO draft report as a 'frightening document' within which direct entry was seen as the most startling element. It wants to ensure that the principle that all police officers 'start on the shop floor' is preserved (Martis, 2006).

Yet the real challenge may be the recommendation by ACPO both to introduce common career paths for non-warranted, partially warranted and fully warranted officers and also to establish opportunities for common career progression. This element of modernisation is likely to reflect, at least in part, the evident success of community support officers and their future expansion. It is also a belated recognition that police support staff now constitute up to one-third of all police force personnel, and their potential skills should be harnessed more effectively by the police service.

\section{PILOTING WORKFORCE MODERNISATION}

Preliminary results of workforce modernisation from the pilot sites are encouraging and should lead to much wider utilisation of the modernisation programme. In the county of Surrey, 26 constables have been replaced with 5 'mixed economy teams' composed of 1 constable, 3 investigative assistants and 1 administrative assistant. The constable becomes the line manager for a small team of trained police staff technicians who exercise limited police powers. By increasing police support staff numbers it has been found that a great deal more service delivery hours can be provided to Surrey's residents. Moreover, an analysis of crime resolution in the county was to reveal that in only a small percentage of cases were the high level skills of a detective actually needed. Most crime dealt with involved handling property, taking statements and personal assistant skills.

In response Surrey has now introduced investigative assistants made responsible for processing most volume crime in the force area. An initial evaluation of the investigation teams suggests there have been big gains. Average investigation time has fallen from 26 to 15 days while the detection rate has risen by 14 per cent. Surrey police report similar positive results with their neighbourhood policing teams. These consist of 1 constable, 3 PCSOs and 1 administrative assistant. Already steep rises in public confidence have been recorded in the pilot sites since their introduction (Police Professional, 2005a, p. 11).

\section{EXPERIENCE OF BEXLEY OPERATIONAL COMMAND UNIT}

Similar results have been recorded at the Bexley pilot site. As in Surrey, an evaluation of traditional investigation procedures was to find that the average investigation time per case was 50 days with 60 per cent of the time engaged on any investigation identified as 'non-investigation work' (Police Professional, 2005b, p. 20). In Bexley the pilot sites have recorded a dramatic fall in investigation time from 50 to 16 days. Detections as a percentage of crime have also increased significantly. For the first time ever, it is 
reported, the detection rate is expected to reach close to 30 per cent of recorded crime (Police Professional, p. 21).

In Bexley police staff now make up a third of personnel employed in crime investigation teams and further expansion in the use of police staff is now planned. This expansion is based partly on the interesting discovery that members of the public appear happy to deal with any member of the Metropolitan police service and that they 'do not seem overly worried if that person is an actual police officer or not' (Police Professional, 2005b, p. 21).

The Bexley pilot's use of 'investigative support officers' has allowed professionally trained detectives to direct their attention to more serious offences. Time made available to them through the use of Investigative Support Officers (ISOs) has allowed more crime to be 'screened in'. As was to be identified by the OCU commander, the first area of interest within the pilot proved to be, perhaps not surprisingly, the investigation and management of crime (MPS, 2006). The first major change emanating from workforce modernisation proved to be ending the system whereby a police investigating officer exercised complete responsibility for each case 'from cradle to grave'.

In Bexley, the current concept of detective officers assuming responsibility for every aspect of a case within which they personally carry out every activity linked to an investigation (including collecting all witness statements and setting up ID parades), has been effectively brought to an end. With 13 ISOs detectives are now able to look at new and more challenging roles. Most of the more mundane duties are made the responsibility of the ISO. The use of ISOs and the new division of labour within the investigation process that this represents, has had a significant impact on the overall length of investigation time taken for each case which has fallen dramatically (MPS, 2006).
Using ISOs has also been matched by the use of volunteers to take on the often extremely time-consuming responsibility of viewing all local CCTV tapes. This has also had an immediate impact in Bexley where it has allowed for more crime to be 'screened in' and also for many more positive leads to be followed up by police investigators (MPS, 2006). In Bexley the aim was now to retain the mixed staffing model as their utility had quickly been appreciated. They had also been made responsible for answering all non-emergency calls from the public. Here it was to be subsequently discovered around a third of non-emergency calls did not in fact require a police response at all (MPS). In Bexley the use of Community Support Officers to deal with these calls had served to 'professionalise the mundane' which police officers often did not want to deal with but which did engage the local community (MPS).

One indication of the way in which workforce modernisation could extend to operational policing had been the use of Community Support Officers on Local Response Teams (LRTs). This was seen as probably the most 'controversial area of police business' and while the Police Federation had made reference to 'mission creep', police officers serving on LRTs were to prove very supportive of the inclusion of CSO's (MPS, 2006). Interestingly, in relation to the expanded use of CSOs, analysis of local police communications in Bexley was to demonstrate that currently police officers were now 19 times more likely to call for PCSOs than were PCSOs to call for police officer support (MPS).

As in other pilot sites the overall assessment of workforce modernisation has proved to be very positive. The extended use of police staff and CSOs had enabled the forces involved to increase their performance and improve their visibility accountability while also contributing to greater consumer satisfaction. Evidence 
from Bexley was to lead the OCU commander to comment critically on the current 'political paranoia' which surrounded police numbers, when the real need was to give greater freedom locally to police managers who should be allowed to use the resources so released where they were most needed (MPS, 2006).

\section{IMPACT OF MODERNISATION}

The implications of the workforce modernisation programme have not, as yet, been fully appreciated. However, some indication of the level of senior management commitment to its realisation has been highlighted by the secondment of a senior Home Office official to the Metropolitan Police Service (MPS) to oversee the introduction of the modernisation programme within that service. It is the Metropolitan Commissioner's intention to show a clear lead in the greater use of police staff within the modernisation process and the creation of more flexible entry points into the service for qualified staff. Along with the mixed economy teams will also go a major expansion in PCSOs. In terms of numbers these are expected to peak at around 24,000 officers in 2008, although there may yet be a case for further expansion thereafter (Haynes, 2006).

These developments are linked to other significant reforms that will impact on the police service. One has been highlighted within the Review into Police Disciplinary Arrangements (Taylor, 2005) within which a major recommendation is that future police disciplinary arrangements should follow the practice laid down by ACAS. This it believes will begin to bring modern management practice into the police discipline system. One further challenge to traditional police shibboleths can be expected to arise ironically from the creation of the Serious and Organised Crime Agency (SOCA) established under the Police Reform Act 2002.
One unintended consequence of the creation of SOCA has been the discovery that it could lead to the probable demise of the 'office of constable' as, within the Police Reform Act 2002, any member of SOCA can now be given all the powers of the constable. These powers can be expected in future to be exercised by, for example, HM Revenue \& Customs officers and Immigration officers, who will be serving within SOCA 'for an indefinite time' (Police Review, 2005). These officers will not, however, be constables but SOCA 'employees'. This is a significant development but can be expected to contribute to the overall workforce modernisation process.

\section{CONCLUSION}

Workforce modernisation, if implemented, could fundamentally alter the policing landscape in England and Wales. It could also help professionalise the police service and finally bring to an end its traditional 'blue collar' status. To achieve this, however, it is clear that many barriers erected over the years to protect and preserve police officer interests, but that now serve to impede service delivery, will need to be abandoned. Many of these would be the first casualties within the detailed programme presented within HMIC's Thematic Report on modernisation of the police service.

There remains, however, a political dimension that could nevertheless act as a brake on the modernisation process. Modernisation is at least in part predicated on expanding support officer numbers by reducing current police establishment. If the proposals outlined at the 2005 ACPO conference by the Chief Constable of Surrey were implemented, it was estimated that the programme could mean a reduction in overall police establishment from the current 140,000 to just over 90,000 nationally (Police Professional, 2005a). This interesting prediction may have explained the unusual 
reticence of the then Home Secretary in his response to the Surrey pilot.

This was entirely explained by the fact that the size of police establishment is now a well-established virility test between the main political parties. Within the world of political party competition a primary concern relates to police numbers rather than what police officers do. For the modernisation programme to begin to unfold, some difficult political challenges will therefore also have to be confronted. How New Labour responds to this challenge in a postmerger environment will provide an important measure of its commitment to workforce modernisation in the police service. It may also provide a litmus test to the government's commitment to meaningful reform within the public sector overall.

\section{References}

Haynes, C. (2006, January). Officers and staff to be trained together under new scheme. Police Review, 24-25.

Herbert, C., \& Gower, P. (2004, July). Happy families? Police Review, 18-20.

HMIC. (2004). Modernising the Police Service: A Thematic Inspection of Workforce Modernisation-The Role, Management and Deployment of Police Staff in the Police Service of England and Wales. London: Home Office.

HMIC. (2005). Closing the gap. London: Home Office.

Home Office. (2005). Report of the Taylor Review of Police Disciplinary Arrangements. London: Home Office.

Jones, M. (1980). Organisational Aspects of Police Behaviour. Farnborough: Gower.
Kaye, T. (1991). Unsafe and Unsatisfactory? The Report of the Independent Inquiry into the Working Practices of the West Midlands Police Serious Crime Squad. London: Civil Liberties Trust.

Loveday, B. (1998). Improving the Status of Police Patrol. International Journal of the Sociology of Law, 26, 161-196.

Loveday, B. (2006a). Size Isn't Everything. Restructuring Policing in England and Wales. Policy Exchange, 44.

Loveday, B. (2006b). Police Reform: Producer Driven or Consumer Led? An Evaluation of the Current Police Reform Agenda. Police Journal, 79, 200-213.

Martin, J. P., \& Wilson, G. (1969). The Police: a Study in Manpower. London: Heinemann.

Martis, R. (2006, February). Federations condemn chief's 'frightening' workforce plan. Police Review, 14-15.

MPS (2006, June). Interview with Chief Superintendent Robin Merrett, Operational Command Unit London Borough of Bexley.

O’Byrne, M. (2001). Changing Policing: Revolution not Evolution. Pangbourne, Berkshire: Russell House.

Police Professional. (2005a, June). Surrey workforce modernisation. The $40 \mathrm{k}$ constable. Police Professional. 12-13.

Police Professional. (2005b, July). BexleyDriving Modernisation In the Met. Police Professional, 20-22.

Police Review. (2005). SOCA officers could spell death of constable role. Police Review, 113(5808), 12-13.

Police Review. (2006). Personal view. Police Review, 113, 17.

Police Superintendents Association. (2004). Moving Policing Forward.

Wilson, O. W. (1950). Police Administration. New York: McGraw-Hill.

Young, M. (1991). An Inside Job. Oxford: Oxford University Press. 